\section{UNIVERSITY \\ OF DEBRECEN}

FACULTY OF

HeALTH

NYÍREGYHÁZA

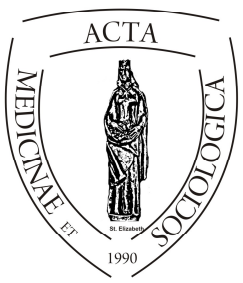

ACTA

MedSoc

VOLUME 6.

2015

\title{
A tankötelezettségi korhatár csökkentésének negatív hatásai
}

\author{
Pap Mónika
}

Debreceni Egyetem, Egészségügyi Kar

\begin{abstract}
The interview-based research reveals the effects of 16 years of compulsory school age in according to the professionals and parents are involved They said the declined compulsory school age is significant support for early school leaving of Roma students. The legal possibility of early school leaving has a negative impact to learning motivation. According to experts, the motivation is mainly due to the negative sample of uneducated parents. It was clear that the difficult financial circumstances show work more favorable light than learning. The public employment which is open for 16-18-year-olds has a strong motivating force. This phenomenon reproduces the problem of undereducation and all consequences: labor market exclusion and unemployment, working-and-povery. According to the respondents the state has the key to solve the problem.
\end{abstract}

Keywords: compulsory school age, early school leaving

Absztrakt. A 16 éves tankötelezettségi korhatár hatásait vizsgáló, interjús kutatásom során feltártam, hogy az érintett szakemberek és a szülők tapasztalatai szerint a leszállított tankötelezettségi korhatár jelentősen támogatja a korai iskolaelhagyást a roma tanulók esetében. A korai iskolaelhagyás legális lehetősége negatívan hat a tanulási motivációjukra. Tanulás iránti motiválatlanságuk a szakemberek szerint főként a negatív szülői mintából, a szülöi iskolázatlanságból fakad. Világosan kiderült, hogy a nehéz anyagi körülmények a tanulás helyett a munka világát tüntetik fel kedvezőbb fényben. Ebben 
nagy motiváló ereje van a 16-18 évesek részére is megnyíló közfoglalkoztatásnak. Ez a jelenség újratermeli a romák körében az alacsony iskolai végzettség problémáját, és annak minden következményét: a munkaerö-piaci kirekesztettséget, a munkanélküliséget, és az alacsony jövedelmek miatt kialakuló, munka melletti szegénységet. A megkérdezettek szerint a probléma megoldásában az állam szerepe a legfontosabb.

Kulcsszavak: tankötelezettségi korhatár, korai iskolaelhagyás

\section{Bevezetés}

Meglátásom szerint a tankötelezettségi korhatár 18 évről 16 évre való leszállítása nem kavart akkora vitákat, amekkorát egy ilyen jelentőségü változásnak kavarnia illett volna. Oktatáskutatók, szociológusok, illetve a gyakorlati szakemberek az oktatáspolitikai döntés idején, majd a bevezetést követöen is leírták a sajtóban, hogy milyen hátrányokkal jár a korhatár leszállítása - föleg a szegregáló, kirekesztett családok gyermekei számára -, de lényegi vita nem zajlott. Nincs tudomásom arról, hogy olyan szakmai érvek hangzottak volna el, amelyek a korhatárcsökkentés pozitív oldalát mutatták volna be. Az egyetlen érv, miszerint aki nem akar tanulni, azt ne erőltessük, inkább hadd menjen dolgozni, számomra inkább politikai állásfoglalás, amely a közbeszéd tematizálására irányul. Hiszen ha ez szakmai érv lett volna, akkor ki kellett volna térnie, hogy milyen hatást gyakorol a családokra és a fiatal pályakezdőkre az, hogy „saját akarata szerint” lényegében képzetlen munkaerőként kerül a nyílt munkaerő-piacra. Milyen perspektívák tárulnak a lemorzsolódók elé, és ezen perspektívák közül melyek azok, amelyek a társadalmilag elfogadott és megbecsült élethez vezetnek. Hogyan hat a gazdaságra az, hogy nyílik egy könnyü út a korai pénzkeresés felé - melyre a nyomorgóknak objektíve nagy szükségük van -, és ezért mind jobban csökken a gazdaság müködéséhez és fejlődéséhez szükséges képzettség megszerzésére irányuló motiváció.

Léteznek persze a tudományos és szakmai fórumokon el nem hangzó, bizalmas körben megfogalmazott érvek is. A többször bukott, túlkoros tanulókkal hiábavalóan küszködő pedagógusok panasza. Az iskolába be nem illeszkedő, deviáns gyerekekkel nem bíró gyermekjóléti családgondozók, gyámügyi ügyintézők sarkos véleménye. Azt azonban nem tudom, hogy ezek a napi, gyakorlati tapasztalon és kudarcokon alapuló vélemények mennyire lehetnek vitaképesek a fentebb említett helyzetben. Vajon a forráshiányos szakmákban dolgozók küszködése mennyire rendszerhiba, vagy mennyiben az egyén hibája - legyen az szakember, vagy diák, szülő, ügyfél -, és bármelyik hiba esetében adekvát válasz lehet-e a javításra a tankötelezettségi korhatár leszállítása. Egyáltalán: megoldott-e bármilyen problémát is ez a döntés? 
Munkám során naponta kerülök kapcsolatba roma családokkal, sorsukat évek óta figyelemmel kísérem, ugyanis 2008 óta szociális ügyintézőként dolgozom egy alföldi nagyközség közigazgatási területén. A Kormány 105/2015. (IV. 23.) Korm. rendelete rendelkezik a hátrányos helyzetü települések besorolásáról és a besorolás feltételrendszeréröl - eszerint a településem halmozottan hátrányos helyzetü. Településemet azért nem azonosítom be pontosabban, mert a kutatásom szempontjából sem a neve, sem egyéb jellegzetessége nem lényeges - úgy gondolom, a kvalitatív módszerrel gyüjtött adataimat az ország bármely pontján gyüjthettem volna, ahol a kérdéses probléma előfordul, jellemző.

Az eljárások során betekintést nyerek ügyfeleim jövedelmi és vagyoni helyzetébe, ezen kívül előtérbe kerül a gyermek tanulói jogviszonya, esetenként a szülők iskolai végzettsége és a lakáskörülmények is, ezzel egy szélesebb látókört adva a családok életére.

Utóbbi években egyre gyakrabban tapasztalom a korai iskolaelhagyást, a korai gyermekvállalást, az iskoláztatási támogatás jelentős számú felfüggesztését a hátrányos helyzetü, elsősorban - sőt, szinte kizárólag - roma tanulók esetében. De nem csak a dokumentumok árulkodóak; sokat beszélgetek a szülökkel is. Azt tapasztalom, hogy a gyermek iskoláztatása, előrehaladása nem kap kellő szerepet az életükben, annak ellenére, hogy elmondják: „, Kell egy iskolai végzettség. ” De gyakran hallom a „Nem akar iskolába menni, minek erőltessem? - már nem tanköteles.” és a „Ha nem akar tanulni, akkor menjen dolgozni, én nem tudom eltartani." mondatokat is. Ezek a munkahelyi tapasztalataim tettek motiválttá abban, hogy megvizsgáljam a tankötelezettségi korhatár leszállításának hatásait.

Magyarországon a jelenleg hatályos rendelkezések szerint a tankötelezettség annak a tanévnek a végéig tart, amelyben a tanuló a tizenhatodik életévét betölti. A rendelkezés a közoktatásról szóló 1993. évi LXXIX. törvény 2012. szeptember 1-jétől hatályos állapota szerint érvényes, melynek értelmében a korábbi, 18. életév betöltéséig szóló tankötelezettségi rendelkezés helyett, a tanulók 16. életévük betöltése után legálisan hagyhatják el az iskolapadot. Úgy gondolom, hogy e rendelkezés hatásaival a roma tanulók esetében külön érdemes foglalkozni. Ez természetesen nem azt jelenti, hogy a nem roma tanulóknál nem fordul elö korai iskolaelhagyás, hiányzás stb., ugyanakkor minden olyan jelenséggel kapcsolatban feltárhatóak az etnikai dimenziók, amelyek az etnikai hátterü szegénység kialakulásának következményeképpen jöttek létre.

Kutatásom során az a kérdés foglalkoztatott, hogy vajon létezik-e valamiféle - legalább szakmai szinten értelmezhető - nyeresége a korhatár leszállításának. És ha létezik efféle nyereség, abból ki részesül leginkább?

Ennek érdekében megpróbáltam 16 éves tankötelezettségi korhatár hatásait feltárni: milyen pozitív, milyen negatív hatásai vannak, és mi az, amit nem érintett ez a rendelkezés. A szakirodalom kritikai észrevételei mentén különös fi- 
gyelmet fordítottam a tankötelezettségi korhatár leszállításának a roma tanulók tanulási motivációjára, valamint a korai iskolaelhagyásra és a lemorzsolódásra gyakorolt hatására.

Tanulmányom első szakaszában kitérek a szegénység etnicizálódására, annak okait pedig elsősorban a kirekesztésben keresem. Ezt követően röviden bemutatom a hazai cigányság élethelyzetének azon jellemzöit, amelyek befolyást gyakorolnak a tanulmányi sikerességre, beilleszkedésre, motivációra. Az interjús módszeren alapuló terepkutatás eredményeit az interjúk kettős fókusza mentén ismertetem: elsőként azt mutatom be, hogy a megkérdezettek szerint melyek a 16 éves tankötelezettségi korhatár pozitív és negatív hatásai, másodsorban pedig arra koncentrálok, hogy mit gondolnak az interjúalanyok, milyen módszerekkel lenne orvosolható, vagy legalábbis enyhíthető a tanulók lemorzsolódása, a képzetlenek iskolaelhagyása.

\section{A szegénység etnicizálódása}

Az etnikai szegénység kialakulásának hátterében minden esetben olyan társadalmi környezet áll, amely eltérően reagál, megkülönböztető módon müködik a különböző etnikumok esetében. A diszkriminatív viselkedés egészen mélyen áthathatja a társadalmat, amely jóval túlmutat azon, hogy egy munkáltató kinek ad munkát, és kinek nem. A kirekesztés beleivódik a mindennapi nyelvhasználatba, a fogalmakba, és ezáltal mindenbe, amelyet az egyének ezen a nyelven leírnak vagy elgondolnak, ezen fogalmak által definiálnak (Hüse, 2008, 2013; Hüse et al., 2014). Létrejön egy mindent átható kettős mérce, amely másképpen méri a többségi társadalom tagjait, és másképpen az etnikai kisebbséget, sőt, ez a kettős mérce elkezdi másképpen mérni a közintézményeket is, mint amilyen az iskolarendszer, attól függően, hogy a többség vagy a kisebbség szempontjából nézünk rá (Hüse, 2011).

Különösen nagy hatóerővel zajlik a kirekesztődés, ha az etnikai szegregációnak történelmi gyökerei is vannak. A romák lakókörnyezetére, lakhatására történelmük során a szegregált körülmények, a kirekesztés volt jellemző. E témák kutatásai szorosan összefüggenek a romák egy-egy településen belüli térbeli elhelyezkedése és a cigánytelepek felszámolása problémaköreivel (Fehér és Virág, 2014). Kemény 1971-es kutatásának tapasztalatai szerint a cigány népesség kétharmada szegregált körülmények között, jellemzően hagyományos telepeken, települések szélén vagy külterületen, de minden esetben a falvaktól elszigetelten élt (kemény, 1976). Az ezredfordulóra a cigány népesség kétharmada többségében cigányok lakta településrészeken élt. Mindeközben megváltoztak a térbeli kirekesztés formái: míg a hatvanas években a cigány családok többsége a 
településeken kívül elhelyezkedő telepeken élt, a nyolcvanas évekre megjelentek az „elcigányosodó” aprófalvak (Havas, 1999; Ladányi és Szelényi, 2004), a városi romák pedig többnyire alacsony státuszú, leromló, slumosodó lakónegyedekbe tömörültek (Ambrus, 1988; Ladányi, 1989; Solt, 1998). A szegregált körülmények mellett fontos tényező a lakóépületek jellege, az infrastrukturális ellátottság. 2004-ben a magyarországi cigányság alig kevesebb, mint ötöde (17,5 \%) szükséglakásban vagy szükségépületben, illetve eredetileg nem lakás céljára szolgáló épületben lakott, közel hetven százalékuk falusias, önálló, egyúttal lakás céljára épületben él. A szükséglakások komfort nélkülinek minősülnek, amely a fürdő és WC helyiség, és jellemzően a közmüvesítettség hiányát jelzi. Az ilyen lakásban élők az ivóvizet jó esetben az ingatlanok udvaráról, rosszabb esetben a közkifolyóból nyerik. A villamos energiával való ellátottság az egyetlen olyan tényező, amely viszonylag magas százalékban állt rendelkezésre 2004ben, de a háztartások 1,4\% -a nem rendelkezett vele. (BABUSIK, 2004). Napjainkra a leszakadó kistérségek roma lakossága a teljes kilátástalanságban él (Hüse, Szoboszlai és Gurály, 2015).

A földrajzi és települési elkülönülés mellett - amely a nyomor látványos zárványait hozza létre - egyéb társadalmi mutatókban is tetten érhető az etnikai szegregálódás. A cigány népesség közel kétharmada a jövedelmi rangsor legalsó tizedébe, mintegy $80 \%$-a az alsó két jövedelmi tizedbe sorolható. A roma háztartások jelentős részének az állami transzfereken és egyéb szociális juttatásokon kívül nincsen állandó jövedelme (Pásztor és Pénzes, 2012). A juttatások közül is háztartás jövedelmének jelentős hányadát a gyermekneveléshez kapcsolódó ellátások jelentik. Ez azt jelenti, hogy az elméletileg koncepcionálisan csak kiegészítő jellegü ellátások a gyermeknevelés többletköltségeinek viselése helyett, a család megélhetésének fő forrásául szolgálnak (Janky, 2004). A halmozódó mélyszegénység pedig alternatív jövedelemforrások, sokszor pedig illegális tevékenységek, valamint kriminalitás megjelenését eredményezi (Fábián, Szoboszlai és Hüse, 2011, 2012; Hüse, Fábián és Szoboszlai, 2013; Hüse, Szoboszlai és Fábián, 2006; Szuhay, 1999). Újabban a jövedelmi helyzet tünik a lakóhelyi szegregálódás legfontosabb összetevőjének, amely területileg és komplexitásában egyaránt kiterjedt szociális problémákhoz vezet.

\section{Az iskolai leszakadás és a motiváció}

A rendszerváltást követően nyilvánvalóvá vált, hogy a hazai iskolarendszer nem képes megbirkózni az új helyzettel, és a romák gyorsan kiszorulnak a munkaeröpiacról annak ellenére, hogy az alsóbb szinteken az iskolázottsági mutatóik javulnak. Bár a cigány gyermekek minden korábbinál jelentősen nagyobb arány- 
ban lépnek be az oktatási rendszerbe, és minden korábbinál tovább bent is maradnak, de romák által tömegével elért oktatási szintek munkaerö-piaci értéke lényegében eltünt, szinte semmi társadalmi haszna nem mutatható ki, ezzel párhuzamosan rendkívül mértékben megnőtt a társadalmi kockázata annak, ha valaki nem végzi el ezt a devalválódott iskolafokozatot, azaz az általános iskolát (Nagy, 2002).

A rendszerváltás első éveit követően megfigyelték, hogy a roma családok életében inkább a gyakorlati ismeretek átadása került elötérbe. Ez a fajta értékrend nem becsüli nagyra az iskolai típusú tudást, ezáltal ez a fajta tudás nem jelenik meg célként, és eszközként sem, amivel bármilyen célt el lehet érni. Az iskolai tanulás nincs jelen pozitív értékként a családokban, mert a szülők nem bíznak abban, hogy az iskolai tanulásba történő befektetés megtérülne (Girán és Kardos, 1997). A roma tanulók többsége sikertelen a magyar iskolarendszerben, a kötelező oktatás által kínált lehetőségeket a roma a társadalom nem tudja kiaknázni (Polónyi, 2002). Az iskolai teljesítménykülönbségek több tényező együttes meglétére vezethetőek vissza: szülők alacsony iskolai végzettsége, szegény életkörülmények, a munkapiacról történő kiszorulás és az ebből fakadó további hátrányok. (Kertesi és Kézdi, 2012). Pedig az iskolázottság fontossága nem vitatható: munkalehetőséget, magasabb keresetet, a család és életforma stabilitását, magasabb várható életkort, a politikai érdekek jobb képviseletét, a diszkrimináció leghatásosabb ellenszerét jelenti. A tudatlanság lényegében hatalomnélküliség, s mindaz, ami ezzel együtt jár: munkanélküliség és alacsony kereset, szegénység és kiszolgáltatottság, széthulló család és rossz egészségi állapot, korai halál, a politikai érdekképviselet hiánya, diszkrimináció (Kertesi, 1995).

Az iskolai sikeresség kulcsfontosságú meghatározója a tanulási motiváció (Nagy, 2000). A tanulás eredményessége a tanulási motívumrendszer fejlettségétől függ, a tanulási képességek ,csak” a tanulás hatékonyságát befolyásolják. A motívumok és képességek fejlődése szorosan egymásba fonódik, egymást segíti, és valószínüsíthető, hogy a motívumok az intelligenciánál szorosabb kapcsolatban állnak a készségfejlődés ütemével, gyorsaságával (Józsa, 2006). Természetesen a roma gyermekek iskolai kudarcai nem vezethetőek vissza egyetlen problémára. Az okok egymással összefüggő halmazáról van szó, mint amilyen az eltérő családi szocializáció, a nyelvi hátrány, az elő́téletek és a szegregáció, de ezek elemei leginkább a tanulási motiváción keresztül fejtik ki hatásukat (Fejes, 2005).

A szülők iskolázottsága és az iskolai motiváltság között szoros összefüggéseket találunk. A gyerekek általában ugyanazt a szintet vagy egy iskolázottsági fokkal többet szeretnének elérni, mint amivel a szülök rendelkeznek, mondhatni a gyermek ambíciója leképezi a szülők meglévő végzettségét (Kende, 2001). Forray és Hegedüs szerzőpáros szerint a tanulásban - a szülők iskola végzettsé- 
génél - erősebb motiváló erő a család polgári életbe való beilleszkedése, és ez inkább az otthon lévő könyvek számával, és az apák munkahelyi integrációjával áll kapcsolatban (Forray és Hegedüs, 1998). Egy, telepszerü körülmények között élő romák körében végzett kutatás során bebizonyosodott, hogy eltérő mértékben ugyan, a tanulási motivációkra pozitív hatást gyakorol a szülői háttér szerep (mennyire tartják fontosnak az iskolát, mennyire figyelnek gyermekeikre), a vallásosság és a gyerekek jövőképe, ezen belül is a belső értékek dominanciája az anyagi értékekkel szemben (hüse, 2015).

Egy gyermek tanulási motívumrendszere életkorával együtt változik. A motívumrendszer fejlődését kisiskoláskorban elsősorban a pedagógushoz füződő viszony és a közösséghez viszonyított eredményesség befolyásolja, majd az életkor előrehaladtával a motiváció csökkenő tendenciát mutat és a belső késztetés helyett inkább az elismerésért, a tanulás gyakorlati hasznáért tanulnak a gyerekek. Ezek a külső befolyásoló hatások a roma tanulók esetében hiányoznak, ahogy a serdülökorban egyre meghatározóbb tanulással társítható jövőkép is (Józsa, 2002). Ennek oka az, hogy a roma családok életstratégiáiban a megszerezhető tudás értéke alacsony, és a munkanélküliség hatására még inkább leértékelödött. Ezen a szocializációs okon kívül a tanulási motiválatlanság másik fő okaként említik az iskola falain belül elszenvedett sorozatos kudarcok hatását, az idegenség élményét, melyek következtében fordul el a cigány diák a tanulástól (kende, 2001).

Az iskolai lemaradások okait vizsgálva három olyan társadalmi mechanizmus azonosítható egyértelmúen, amely statisztikailag nagy valószínüséggel, okságilag jól indokolható módon alacsony teljesítményhez vezet. Minden egyéb tényezô változatlansága esetén, gyengébb iskolai teljesítményt nyújtanak azok a gyerekek:

- akiknek az átlagosnál rosszabb az egészségi állapota,

- akik otthoni-családi környezetükön belül kevésbé férnek hozzá a készségeik fejlődéséhez fontos erőforrásokhoz és tevékenységekhez, illetve

- akik az iskolai pályafutásuk során nem jutnak hozzá a minőségi oktatási szolgáltatásokhoz és motiváló iskolai környezethez (Kertesi és Kézdi, 2012).

A rossz egészségi állapot, a koncentrálási képességet befolyásoló krónikus betegségek rontják a tanulási teljesítményt, ezen kívül jelentős hiányzásokhoz vezetnek. Az otthoni nevelési környezet, tevékenységek, eszközök, tárgyi környezeti feltételek, viselkedési minták jelentősen befolyásolják a gyermek kognitív fejlődését és a gyermek érzelmi stabilitásának a családi nevelési gyakorlatban gyökerező biztosítékait. Ahogy az értelmi és nyelvi fejlődést stimuláló környezeti feltételek és tevékenységek hiánya gátat szab a tanuláshoz szükséges alap- 
készségek fejlődésének, úgy a család életében bármilyen oknál fogva jelenlevő stressz vagy az érzelmi támogatás hiánya is negatívan hat a készségek fejlődésére és rombolja az iskolai teljesítményt. A minőségi oktatás leginkább két dolgot jelent: hatékony és eredményes tanárokat és olyan osztálytársakat, akiktől tanulni lehet, vagy akik a tanulás szempontjából motiváló környezetet jelentenek. A tanári minőség és a kortárscsoport összetétele egymással is szorosan összefügg (Kertesi és Kézdi, 2012).

\section{Tankötelezettség, lemorzsolódás}

A tankötelezettségi korhatár felső határa jellemzően a 16. életév volt. 1996-ban ami Európában az egész életen át tartó tanulás (lifelong learning) éve volt - határozott a magyar parlament a tankötelezettség felső korhatárának 18 évre történő emeléséről (Mártonfi, 2011). Az felmenő rendszerben történő bevezetés alapján a 2009/2010-es tanévben volt először kötelező a 18 éveseknek iskolába járniuk. E rendelkezés által Magyarország rövid időre bekerült azon kevés európai országok sorába, ahol a legmagasabb a tankötelezettség, ugyanis Európa legtöbb országában 15-16 éves korig tart a tankötelezettség (Istenes és Péceli, 2010).

A roma tanulók oktatásával összefüggő kérdések - így a tankötelezettség teljesítse is - évek óta napirenden vannak. Az irodalmak a romák és a többség közötti kulturális szakadékról, az alacsony teljesítményről, a lemorzsolódásról, és a felzárkóztatás nehézségeiről szólnak. A tankötelezettség teljesítésével kapcsolatos nehézségek kiemelt színtere a középiskola. Jellemzően az iskolai végzettséget adó állomás falai között érik el a tanulók tankötelezettségi koruk felső határát. A középiskola - mind a tankötelezettség, mind a tanulás iránti motiváció vizsgálatok szempontjából - kiemelt helyszíne a kutatásoknak.

A roma és nem roma tanulók továbbtanulási esélyei az átlaghoz képest roszszabbak, és drámai különbség van abban is, hogy hány éves korban fejezik be az iskolát, illetve abban, hogy befejezik e egyáltalán (Babusik, 2003). A továbbtanulás helyszínének megválasztásában a legszembetünőbb a különbség, a roma tanulók többsége szakiskolában szeretne továbbtanulni (Kiss és Gordos, 2003). Mártonfiék tankötelezettséggel kapcsolatos kutatásának helyszíne is a szakiskolák, illetve a speciális szakiskolák voltak, ő úgy fogalmazott, hogy főként ezekben az iskolákban tanultak a gyengébb adottságú, többségükben komoly szociális hátrányokkal küzdő, nagy arányban roma származású diákok. A kutatás a tankötelezettség teljesítésével, teljesíthetőségével kapcsolatos gondolkodásra fókuszált mind a diákok, mind az iskolaigazgatók részéről. Az eredmények szerint a tanulók (speciális szakiskolai tanulók 31 százaléka, szakiskolai tanulók 21 százaléka) jelentős százaléka korábban komolyan gondolt már arra, hogy végzés 
előtt megszakítja tanulmányait. A szülők 17, illetve nyolc százaléka preferált volna egy ilyen döntést, és ilyenkor - nagyjából az esetek felében (nyolc, illetve öt százalékban) - a diák is hajlott erre, és mégis eljutott a szakmunkásvizsgáig. Ezek magas aránynak számítanak, hiszen a lemorzsolódott diákok számán felül értendőek. A sikeres befejezésben komoly szerepet tölt be az oktatás minősége, a pedagógusok munkája, de emellett szerepe volt a tankötelezettség jogi kényszerének is, amely hozzásegítette e fiatalokat - egy korosztályban jóval több, mint ezer tanulóról van szó - a szakmaszerzéshez. A felmérés szerint a végzős szakmunkások legalább 15-25 százalékánál nagyon komoly kockázata volt a korai lemorzsolódásnak (Mártonfi, 2011).

A 2001. évi népszámlálási adatok szerint - a 16 éves tankötelezettségi korhatár mellett - 16 éves életkorig szinte mindenki tanul, míg 17 éves kortól kezdve ugrásszerüen megnő azoknak az aránya, akik középfokú végzettség nélkül kilépnek a nappali tagozatos oktatásból. Jelentős eltérések figyelhetők meg az iskolázatlan szülök gyerekei között is iskolai pályafutásukban attól függően, hogy roma vagy nem roma tanulókról van-e szó. Bár a roma fiatal korcsoportokban 2000 és 2008 között dinamikusan növekedett a roma tanulók iskolázottsága, de iskolázási lemaradásuk a felzárkózás ellenére is óriási maradt. Külön vizsgálva a roma és nem roma népességet jól látható, hogy a romák között különösen sokan vannak azok, akik csak a tankötelezettségi korhatár eléréséig tanulnak. Érdemes megjegyezni, hogy a korai iskolaelhagyók aránya a nem roma népességben is megnő a tankötelezettségi kor elérése után, bár kisebb mértékben, mint a romák esetében (Hermann és Varga, 2012).

A cigány családok életében a gyermek továbbtanulásának anyagi vonzatai igen lényegesek. A mindennapi anyagi gondok, a túlélés mellett a gyermek képzésének fontossága eltünik, vagy másodlagossá válik (Forray, 1997), ezért az átlagosnál hamarabb elvárják, hogy az utódok segítsenek a családfenntartásban (Fejes, 2005). A középiskolás korú roma gyerekek a tradíciók szerint már családalapításra érettnek számítanak (Liskó, 2002). Ezekkel a mintákkal, modellekkel, magatartási módokkal azonosulnak. Ha a magasabb szintű iskolázás neki „túl sok vagy túl jó vagy bizonytalan/ismeretlen", akkor saját döntését ennek a folyamatnak az eredményeként úgy hozza meg, hogy beilleszkedjék a szocializációs környezetének elvárásaiba. Ebböl következik, hogy elhagyja az iskolát, lemorzsolódik (Forray és Pálmayné, 2010).

A korai iskolaelhagyás mutatója Magyarországon 2010-ig lassú ütemben csökkent 10,5\%-ra, majd 2010-2012-ig ismét növekedés volt tapasztalható. Területi elosztást tekintve, az Észak-Alföld és Észak-Magyarországi régió van a korai iskolaelhagyás tekintetében legkedvezőtlenebb helyzetben (Mártonfi, 2013a). 
Az iskolai lemorzsolódáshoz különböző egyéni okok vezetnek. A szociológiai vizsgálatok, felmérések a „valós okokat” kevéssé, de azt tudják mérni, hogy az iskolák igazgatói mely tényezőket tartják a lemorzsolódás legfőbb okainak. Ezek sorrendben:

1. A tanulók gyenge tanulási motivációja

2. A sok hiányzás

3. A tanulók gyenge felkészültsége

4. A tanulók gyenge képességei

5. A tanulók rossz szociális háttere

6. Magatartási problémák

7. A tanárok nem megfelelő módszertani felkészültsége

8. A tanárok nem megfelelő motivációja

9. A tanárok nem megfelelő szakmai felkészültsége (Fehérvári, 2008).

Fontos megjegyezni, hogy a kvalitatív módszerrel végzett vizsgálatok hangsúlyozzák, hogy bár a lemorzsolódás kifejezés egy egyszeri eseményre utal, az kifejezetten folyamat jellegü, és bár a történetek tipizálhatók, minden lemorzsolódási történet egyedi, és egyedi beavatkozást is igényel, igényelt volna. A fenti és további tényezők nagyon gyakran együtt, egymást felerősítve viszik egy olyan pályára a fiatalt, amely a program, esetleg az iskola otthagyásához vezet. Két konkrét jelző eszközt viszont könnyü azonosítani, amely a közelgő lemorzsolódás veszélyére figyelmeztet:

1. Az igazolatlan hiányzás mértéke. Ez korán figyelmezteti az iskolát és a szakembereket, hogy beavatkozás nélkül nagy eséllyel kimarad a diák. Az igazolatlan hiányzás mögötti okok azonban sokfélék lehetnek, maga a hiányzás csak tünet.

2. Az általános iskolai évismétlés. Aki az általános iskolában megbukott, az a tankötelezettség miatt még általában beiratkozik ugyan a szakiskolába, de legalább 70\%-os eséllyel nem jut el a szakmunkásvizsgáig (Mártonfi, 2013b).

Kertesi és Kézdi (2010) szerzőpáros szerint a roma kisebbséghez tartozó fiatalok körében a lemorzsolódási mutató kiemelkedően magas: csupán 22 százaléka fejezi be felső középfokú tanulmányait. A legnagyobb lemorzsolódás a szakiskolákban tapasztalható, ahol többnyire a roma tanulók tanulnak. Az állam ezért lemorzsolódás megelőzésére tett intézkedéseiben is főként a szakiskolákat célozza meg.

Az állam különböző eszközökkel igyekszik csökkenteni a lemorzsolódást, a korai iskolaelhagyást. Az intézkedések különösen a középiskolákat, azon belül is a szakiskolákat célozzák meg, hiszen utóbbi a lemorzsolódás legjelentősebb 
színtere. A lemorzsolódás hátterében tehát több tényező együttes fennállása is húzódhat, ezért a probléma komplex - több oldalról történő - megoldása hozhat jelentős eredményt. Az intézkedések többnyire az elöbbiekben ismertetett két tényezőre (igazolatlan hiányzás, évismétlés) irányulnak, és alapvetően két kategóriába sorolhatóak:

1. Szankciók: az iskoláztatási támogatás felfüggesztése; tankötelezettség megszegése esetén szabálysértési eljárás

2. Ösztönző kedvezmények, juttatások: Integrációs Pedagógiai Rendszer (IPR); Arany János Tehetséggondozó Program, Arany János Kollégiumi Program és Arany János Kollégiumi- Szakiskolai Program; Útravaló MACIKA ösztöndíj program; szakiskolai ösztöndíj program; szakiskolákban tanulók tanulói szerződése; köznevelési Hídprogramok; felnőttképzés lehetősége; családi adókedvezmény.

Az általam a gyakorlatban észlelt helyzet erős kételyeket ébreszt bennem, hogy vajon ez a szankcionáló-ösztönző rendszer képes-e ellensúlyozni azokat a negatív hatásokat, amelyek eddig is sikeresen gátolták a roma tanulók iskolai sikerességét, és amelyek - számomra úgy tünik -, a tankötelezettségi korhatár leszállításával még erősebb befolyást gyakorolnak. Ugyanakkor nem kétlem, hogy saját személyes tapasztalataim érvénye nem terjedhet túl a saját szakmai munkámon, ezért igyekeztem a témában érintett teljes szakmai környezet tapasztalatait öszszegyüjteni a kutatómunkám során.

\section{Anyag és módszer}

Kutatói kérdésem megválaszolására a következő négy területen végeztem interjús adatgyüjtést: oktatás, segítő tevékenység, hatóság, szülők. Az oktatás területéről egy általános iskolai és két szakiskolai igazgató segítette tapasztalataival a munkámat. Három családgondozó képviselte a segítő szakmát, a hatóság részéről pedig egy gyámhatósági, egy munkaügyi és egy szabálysértési ügyintéző vett részt a kutatásban. A szülők részéről három roma származású szülőt (két édesanya, egy édesapa) segített az adatgyüjtésben.

Az interjúim két fő kérdés mentén zajlottak: az egyik a tankötelezettségi korhatár hatásaira, a másik a felmerülő problémák megoldási javaslataira fókuszált. Az beszélgetések természetesen terület specifikus kérdésekkel bővültek ki.

A 16 éves tankötelezettségi korhatár azokat érinti először, akik a 2012/2013-as tanévben kezdik középiskolai tanulmányaikat. Ebből kifolyólag két teljes tanév, és egy fél tanév statisztikai adatai, illetve tapasztalatai álltak rendelkezésemre. 


\section{A tankötelezettségi korhatár pozitív és negatív hatása az iskolaigazgatók szerint}

A megkérdezett igazgatók készséggel álltak rendelkezésemre. Kutatási helyszíneim közül csak az általános iskolában volt megállapítható a roma tanulók valós aránya (98\%), ugyanis minden szülő nyilatkozott erröl a délutáni tehetséggondozó, felzárkóztató, fejlesztő foglalkozásokban történő részvétel miatt. A szakiskolákban csak bizonyos lemorzsolódás megelőzését szolgáló programokban nyilatkoznak a tanulók roma származásukról, miáltal kevés tanuló kerül be ezekbe a programokba, ez a szám nagyon minimális. Az igazgatók véleménye szerint a két szakiskola tanulóinak 60-60 \%-a roma származású, ezt a körülbelüli arányt a tanulók lakóhelyi környezete és nyilvánvaló rasszjegyek alapján állapították meg. Az interjúalanyaim gyakran hivatkoztak a hátrányos és halmozottan hátrányos helyzetü tanulókra, az utóbbi kategóriába tartozó tanulók jelentős százaléka roma származású.

A megkérdezett pedagógusok ugyanazt látták a rendelkezés fő pozitív hatásának: Nem kell azokat a gyerekeket az iskola falai között tartani, akik nem akarnak tanulni. Több gyerek számára ez kényszer volt, ami magával hozta a rengeteg hiányzást, a deviáns magatartást, mellyel zavarták a tanulni vágyókat. „Nagyon nehéz egy olyan gyereket tanitani, aki nem akar tanulni, és folyamatosan csak zavarja az órákat, agressziv, elszökik, abszolút motiválatlan." (általános iskolai igazgató) Ezt a rendelkezést statisztikai és a tanítási morál szempontjából is jónak találják. „Amíg 18 év volt a tankötelezettségi korhatár gyakran elöfordult, hogy a gyermek a 9. évfolyamon töltötte mind a négy évet, és a szakma megszerzése nélkül került ki az oktatási rendszerböl."(szakiskolai igazgató)

Pozitív hatásként említették az igazgatók, különösen a két szakiskolai igazgató a magántanulói státuszok csökkenését. „A 18 éves tankötelezettség idején 34 magántanulója volt az iskolának, ezek azért voltak, mert nem találtunk más megoldást arra, hogy a gyerek nem akar iskolába járni, de ne kelljen a szülöt megbüntetni stb. Kérte a szülö, mert tehetetlen volt már, a családsegitó javaslatával magántanuló lett. Ezt lemorzsolódásnak tekintem, mert ezek a gyerekek nem tudnak önállóan otthon felkészülni, nem is tudtak levizsgázni, ugyanúgy ott van az utcán, hivatalosan pedig az iskolában." (szakiskolai igazgató)

A rendelkezés negatív hatása, hogy hozzájárul a lemorzsolódáshoz. Mindannyian egyetértettek azzal, hogy a tankötelezettségi korhatár szoros összefüggésben áll ezzel a jelenséggel, különösen a roma származású tanulók esetében. Ezt az összefüggést viszont máshogyan értelmezték. Kétféle megközelítést tapasztaltam: 
1. A lemorzsolódási arány fömutatója a 16. életév betöltése utáni iskolaelhagyások száma, tehát azok, akik a végzettség megszerzése előtt hagyják el az iskolát. Ebből a szempontból jelentős a korai iskolaelhagyók számának növekedése. „Amíg 18 év volt a tankötelezettség, valamilyen módon az iskolában tudtuk tartani a gyerekek bizonyos részét, most a tankötelezettség lejártakor azok a gyerekek is kiiratkoznak, akik egyébként kis ráhatással szakmát szereztek volna, igy nagyon sok olyan embere lesz a társadalomnak, akik ugyan többre képesek, mégis 8 általános iskolai végzettséget tudnak csak felmutatni." (szakiskolai igazgató)

2. A másik megközelítés szerint a lemorzsolódást több szempontból kell vizsgálni: „Ha azt nézem meg, hogy a 9. évfolyamra belépők közül hány jut el a szakmai vizsga megszerzéséig, akkor nem nött a tankötelezettségi korhatár változása miatt a lemorzsolódás. Ha azt nézem, hogy a 9. évfolyamon hányan maradnak ki, akkor igen. Én lemorzsolódásnak érzem azt is, ha a gyermeket az iskola falain belül tartjuk, de iskolai végzettségben nem tud elörébb lépni, tehát ugyanúgy általános iskolai végzettséggel hagyja el a középiskolát."(szakiskolai igazgató)

Jelentős tehát azoknak a száma, akik 16. életévük betöltése után elhagyják az iskolát. A szakmai végzettséget megszerzők számát tekintve viszont nem jelentős a csökkenés, ami azt jelenti, hogy a 18 éves tankötelezettség hatályakor is sok volt a sikertelenül végzők száma, illetve, hogy a korai iskolaelhagyás legfőbb okának nem a tankötelezettségi korhatárt tekintik. Az válaszokat összevetve az okok az alábbiak szerint rangsorolhatóak:

1. A tanulás iránti motiválatlanság: A szülők jellemzően alacsony iskolai végzettségüek, nem prezentálják gyermekeik felé a tanulás fontosságát, értékét. Nagyon kevés, vagy egyáltalán nincs pozitív példa előttük, de ide tartozik a szülöi felelötlenség is. A motiválatlanságból adódnak az igazolatlan hiányzások, és a sikertelen tanévek is.

2. A szegénység, életkörülmények, a munkanélküliség: Gyakori probléma, hogy nem tud buszbérletet venni a szülö, de beszámoltak olyan esetről is, amikor nem volt a gyermeknek cipője, amiben iskolába mehetett volna. „,Van olyan gyermek, aki egész nap nem eszik semmit.”(szakiskolai igazgató) A gyermek látja, hogy nagy a munkanélküliség, nem látja az értelmét a tanulásnak. „Apám sem tud elhelyezkedni, hiába van szakmája. "(szakiskolai igazgató idézi a tanulót)

3. Tankötelezettségi korhatár:_A tanulás iránt motiválatlan gyermek legális lehetősége iskolaelhagyásra a befejezés előtt. „,...ha megengedjük azt, hogy 16 éves koruktól ne tanuljanak ezek a gyerekek és 16 éves korukig szakmát nem szereznek, meg lehet nézni, akár településszinten is, hogy milyen vég- 
zettség összetétel lesz, milyenek lesznek a felnöttek és mennyiben segíti elö a késöbbi munkanélküliség emelkedését is. Siralmas lesz a helyzet." (általános iskolai pedagógus)

A felsorolt három ok mindegyikéhez besorolható a korai gyermekvállalás problémája. A pedagógusok ezt a problémát mind a tanulási iránti motiválatlanság (szülői példa), mind a szegénység, mind a tankötelezettségi korhatárral kapcsolatban megemlítették. Fontos, hogy a gyermekvállalás egyfajta menekülö út azoknak a lányoknak, akik nem akarnak tanulni. „,...nem mondom, hogy nem találkoztam olyannal, akinek ez egy menekülés volt, hogy ne kelljen iskolába járni, már öt-hat hetesen beadták a magántanuló kérelmet."(szakiskolai igazgató).

Ez a probléma különösen fajsúlyos a három éves képzésre áttérő szakképző iskolák esetén, miáltal a szakmai tárgyakat elkezdték 9. évfolyamon oktatni. Ez azt jelenti, hogy a gyakorlati oktatás megkezdődik, amelyen a szakképzési törvény értelmében kötelező a részvétel. A magántanulói státusz a köznevelési törvény értelmében viszont minden óra alóli mentesítést jelent, az így kialakuló joghézag értelmében magántanulóként is részt kell venni a gyakorlati órákon. „Ha ilyen feltételek mellett visszaállitanák a 18 éves tankötelezettségi korhatárt, akkor egyszerüen nem tudom, hogy ezt a problémát hogyan kezelnénk, most sem tudjuk kezelni 9. évfolyamon, elég sok terhes kislányunk van, nem lehet magántanuló, a roma lányok pedig nem vállalják be, hogy terhesen járjanak iskolába, ha megszülnek, pedig azért nem vállalják be, mert bár lenne, aki vigyázzon a csecsemöre, de mindig találnak kifogást. Az a jellemzö, hogy megtudja, hogy terhes és megjelenik a szülövel együtt. Ilyenkor legalább ott a lehetöség, hogy megszüntetethetö a tanulói jogviszony. Utána visszajöhetne, ha fontos lenne neki, hogy szakmát tanuljon, de nem fontos neki." (szakiskolai igazgató)

\section{A lemorzsolódás megakadályozásának lehetőségei}

A megkérdezett igazgatók szerint a legfontosabb a tanulás, mint érték közvetítése lenne. Ez a legnehezebb feladat, mert ennek a gyermek szocializációja során kellene kialakulni a szülői minta alapján, de a roma gyerekeknél ez a minta jellemzően hiányzik. Hiába közvetíti a tanulás fontosságát az iskola, ha otthon ennek az ellenkezőjét tapasztalja a gyermek. A lemorzsolódás megelőzését szolgáló programok (pl. ösztöndíjprogramok) a pedagógusok szerint ebből a szempontból sikertelenek: a tanulás, mint érték nem alakul ki a gyermekben, és a gyermek taníttatása, mint kötelezettség sem erősödik a szülőben. Mindennek 
ellenére fontosnak találják az ösztöndíjprogramokat, mivel ezek a családok nehéz anyagi körülmények között élnek, és a pénz talán a legerősebb motiváló erő számukra. Az ösztöndíjért cserébe a tanulónak bizonyos minimum átlagot kell elérni, és nem hiányozhat igazolatlanul. Pozitívum, hogy a gyengébb teljesítményü tanulók részére is van pályázat, már 2,5-ös tanulmányi átlaggal is részt lehet venni. A minimum átlag feletti teljesítmény magasabb összegü támogatást jelent.

A programok legjelentősebb pozitív hatása a megkérdezettek szerint az igazolatlan hiányzások csökkenése, bár ez nem minden esetben jelenti a rendszeres iskolába járást - több esetben a szülök odafigyelnek arra, hogy orvosi igazolás legyen a hiányzott időszakra. A program tanulmányi teljesítményt növelő hatása is csekély, mivel a tanulók a minimum tanulmányi átlag tartására törekednek. További pozitív hatása, hogy mentortanár kíséri figyelemmel a tanuló iskolai útját, rendszeresen kapcsolatot tart a szülőkkel, ezáltal erősödik a szülő, pedagógus, gyermek együttmüködése. A program sikerét évről évre csökkenőnek látják, ezen kívül kevés gyermek kerülhet csak be. Sok családnak az ösztöndíj a háztartás fő bevételi forrása, gyakorlatilag a gyermeknek azért kell jól tanulnia, mert ő tartja el a családot. A szülő emiatt motivált, a gyermek lelkesedése viszont előbb-utóbb alábbhagy, és ha bármi miatt elveszítik az ösztöndíjakat, a diákok teljesen feladják, és nem is tudják visszaszerezni a motivációjukat.

Bizonyos programok a feltételrendszerük miatt sikertelenek. Amennyiben a tanuló ront, és a minimum tanulmányi átlag alá esik, vagy többet hiányzik igazolatlanul a megengedettnél, elesik az ösztöndíjtól és vissza kell fizetnie az addig felvett teljes összeget. Ebben az esetben a mentortanár díjazását is vissza kell fizetni. Ez a program egyáltalán nem ösztönző hatású: „Amikor így indul egy pályázat, nem mindenkit mer a pedagógus sem bevállalni, mert megdolgozik valamiért, amit később vissza kell fizetni." (általános iskolai igazgató)

Az igazgatók szerint a szülöket célszerü lenne motiválni a bentlakásos iskolák választásában. A gyerekek látnák a komfortos és a komfort nélküli otthoni körülmények közötti különbségeket, és ez által kialakulna bennük az igény erre, rögzülnének a higiéniai szokások, és csak hétvégén éreznék az infrastrukturális ellátottság hiányát.

Szakiskolai igazgatók támogatnák a szakiskolában egy ún. előkészítő év bevezetését. A 8 . osztályt elvégzett tanuló nem tudja eldönteni milyen szakma lenne számára megfelelő, nincs rálátása a szakmák világára. „Ha a tanuló a szakképzö iskolában egy elökészitö évet tölthetne, felmérhetné milyen lehetöségei vannak, mit szeretne elérni, megismerkedhetne az elérhetö szakmákkal, és csak ekkor kapna lehetöséget a választásra, akkor nagyobb esélyt látnék arra, hogy kitartó lenne és szakmát szerezne." (szakiskolai igazgató)

Az igazgatók többsége fontosnak találja a szankciók következetes alkalmazását, amelyek a szülői felelősséget közvetítik. Egyetértenek a szabálysértési eljárásokkal, amennyiben az igazolatlan hiányzás meghaladja a megengedetett. 
Az iskolázatási támogatás felfüggesztésének, a szabálysértési eljárásnak, a tanulói juttatások megvonásának már hatásosnak kell lennie. Fontosnak találják, hogy legyen „elrettentő” példa a szülők elött.

A megkérdezettek mindegyike egyetértett az iskoláztatási támogatás felfüggesztése jogintézményével: a szülő érezze, hogy kötelessége a gyermek taníttatása, és érezze a saját bőrén, hogy ennek elmulasztása milyen következményekkel jár. A jogintézmény sikerességéről már más a vélemény a szakiskolákban és az általános iskolában. A szakiskolai igazgatók elmondták, hogy ezzel is az a baj, hogy bár az igazolatlan hiányzások tekintetében pozitív hatása van, de ez nem jelent rendszeres iskolalátogatást, mert a szülő inkább szerez orvosi igazolást. „Van olyan, aki az egész évet hiányozza. Van olyan tanuló, aki egyetlen napon sem volt még, hozza az orvosi igazolást, de ennek az az oka, hogy neveli az egyéves gyermekét"(szakiskolai pedagógus) A szakiskolai igazgatók tapasztalata, hogy az a szülö, aki emiatt elveszíti az iskoláztatási támogatást nehezen vagy egyáltalán nem szerzi vissza. Az általános iskola igazgatója inkább a viszszatartó erőről számolt be, a szülők motiváltabbak és járatják a gyermeket iskolába. „Amikor már több hónapon keresztül érzik a saját börükön a hiányát, onnantól kezdve már kezd fontossá válni, tehát van visszatartó ereje. Van egy tanuló, akitöl kétszer megvonták, és azóta nem hiányzik, fel is nött valamelyest, kezd felnötté válni és átérezni a helyzetet. "(általános iskolai igazgató)

Meglátásom szerint az eltérő vélemények abból adódnak, hogy a középiskolás serdülőkorú roma gyermekre nehezebben tudnak már hatni a szülők, hiszen egy roma serdülő fiúgyermek már felnőttnek számít. Ezt felerősíti a lakóhely és az iskola távolsága, nincs rálátása a szülőnek a gyermekére, ezzel ellentétben az általános iskoláskorú gyermekre általában igen.

Állami szinten szükség van munkahely-teremtésre, mert ennek kellene lennie az ösztönző folyamat végső állomásának, ezért megy a küzdés. „Azt kell látniuk, hogy nem hiába tanulnak, mert lesz munkájuk, de nem ez a tapasztalatuk, el is mondják, hogy xy-nak is van szakmája, kereskedöként végzett és mégis otthon van egész nap, nincs munkája. Addig, amig nem tudunk munkahelyet biztositani a szakmunkásképzöböl kilépö fiatalok nagy részének, addig nem motiválja öket a szakma megszerzése." (szakiskolai igazgató)

A munka kapcsán vetődött fel a közmunka hatása, kíváncsi voltam az ezzel kapcsolatos véleményekre. Hogyan látják a gyerekek vonatkozásában a közmunkaprogramok előnyeit, hátrányát? A közmunka többnyire pozitív hatásáról számoltak be: „Aki közmunkán van, mást vár el a gyerektöl, aki tartósan közmunkán van, annak megváltozik kicsit az iskolához való hozzáállása, fontosabbá válik, hogy a gyerek jár-e, itt dolgoznak, már csak arra is jó, hogy beszaladnak megkérdezni, hogy a gyerek bejár-e, ezekkel a szülökkel kicsit javult a kapcsolat. Csak segiti öket, hogy menjenek affelé, hogy csak munkából, pénzböl kellene megélni, csak azután kellene az a lehetöség, hogy igenis, aki képes megállni a 
helyét, ki tud emelkedni a többi közül legyen végleges munkahelye, nem az hogy lejár, üldögéljél félévet és akkor hátha lesz megint valami” (szakiskolai pedagógus) Ugyanerről az általános iskolai igazgató: „A közmunka jelent valamit, de nem mindegy, hogy kényszerböl dolgozik valaki, vagy azért dolgozik, mert meg szeretne élni. Gyerek, gyerekfejjel gondolkodik, ha józanon gondolkodik a szülö, és a gyerek azt látja, hogy a munka az első, akkor ez rögzül belé, és az lesz neki az etalon. A közmunka két-három éve megy, és igazából még nem rögzült, nem épült beléjük."

A tankötelezettségi korhatár 18. életévre történő visszaállítása megoldás lenne a korai iskolaelhagyás mérséklésére az igazgatók szerint. Úgy gondolják, hogy a sikeres ösztöndíjprogramok, a szankciók következetes alkalmazása, a munkahelyteremtés mellett ez a rendelkezés működőképes lenne, és talán pozitívan hatna a tanulás iránti motivációra. Bár a negatív tapasztalataik miatt a 16 éves tankötelezettséget preferálják, mindannyian kiemelték, hogy nem mindegy, hogy a gyerek az utcán cselleng, vagy felügyelet alatt van, biztosítva van számára az étkezés, télen a meleg, és talán rábírható, hogy tanuljon.

$\mathrm{Az}$ általános iskolai igazgató hangsúlyozta a szülő-pedagógus-gyerek együttmüködésének erősítését, melynek egyik eszköze a családlátogatás. Nagyon nagy hátrány, hogy nem ad lehetőséget a köznevelési törvény a gyermekés ifjúságvédelmi felelős alkalmazására. Az általános iskolában korábban ő heti 40 órában csak ezt a feladatot látta el, oda tudott figyelni minden gyerekre, fel tudta tárni a rejtett problémákat, általa alakult ki a szülö és az iskola közötti bizalmi kapcsolat. Ez a feladat most ráterhelődött az egyébként is leterhelt pedagógusokra, osztályfőnökökre. „Egy olyan intézményben ahol nem sok HHH-s és veszélyeztetett gyermek, van a pedagógusok osztályfönökök is el tudják ezt a feladatot látni, ahol sok van, ott nem." (általános iskolai igazgató) Egy halmozottan hátrányos helyzetủ településre nagyobb számú segítő szakember kellene, a családgondozók is leterheltek. „Többet ülnek a papír mellett, mint hogy segitsenek, létszámukat meg kell emelni, hogy aktív munkát tudjanak végezni" (általános iskolai igazgató). Szociális munkásokra van szükség, akiket az iskolában is alkalmaznának, mert hallják, hogy van ilyen, de ebből nem érzékelnek semmit. A szakiskolai igazgatók is egyetértenek a gyermek- és ifjúságvédelmi felelős szükségességével. A pedagógusoknak nincs erre idejük, illetve az anyagi háttere sem biztosított, mivel különböző településekről járnak a gyerekek, jelentős anyagi vonzata lenne a családlátogatásoknak. A mentortanárok a pályázati kötelezettségük révén tartják a kapcsolatot a családokkal, de ez kevés. A szakiskolák leginkább a gyermekjóléti szolgálatok közremüködésével igyekeznek feltárni a problémákat. Sajnos gyakran azt tapasztalják, hogy semmitmondó válaszok jönnek vissza, úgy gondolják, hogy ez a kevés idő, és a létszám miatt van így. A létszámukat növelni kellene, több segítő szakember kellene, mert nagyon szükség van a munkájukra. 


\section{A tankötelezettségi korhatár pozitív és negatív hatása a segítő szakma szerint}

A rendelkezés statisztikailag mérhető pozitív hatása az, hogy az iskolalátogatás problémáival kapcsolatos jelzések száma csökkent, de ez egyedül ennek a rendelkezésnek köszönhető, amely megszünteti az eljárási kényszert. Egyéb szempontból semmi sem változott, 16 életév alatt még mindig sok az iskolalátogatással kapcsolatos probléma.

A segítő szakemberek igen negatívan ítélik meg, hogy sok olyan gyereket kiíratnak a szülők, akik egyébként folytatnák az iskolát. „,...most van olyan 16 éves 8. osztályos tanulóm, aki menne tovább tanulni, de a szülö nem akarja, mert mire kijárja a nyolcat betölti a 16-ot és nem akarja beiskoláztatni, és a gyerek a szülö tudta nélkül kitöltette a jelentkezési lapot.” (családgondozó) Ennek oka, hogy szülő nem tudja finanszírozni a taníttatást, rábeszéli a gyereket, hogy regisztráljon a munkaügyi központban és elvárja, hogy dolgozzon, pénzt keressen. A szülők leginkább azzal érvelnek, hogy pályakezdőként rájuk nagy támogatást kapnak a munkáltatók és ezért majd alkalmazni fogják őket. A családgondozók is tapasztalják, hogy a közmunkaprogramokban erre már van lehetőség, viszont más munkáltatók nem fogják alkalmazni ezeket a gyerekeket, hiszen fiatalkorúak, ha bármi történik a szülö felelös értük. Ez a fajta hozzáállás egyre gyakoribb, és egymást is motiválják ebben. A másik érv, amit a családok részéről tapasztalnak, hogy a munkaügyi központok által finanszírozott tanfolyamok között majd talál a gyerek olyat, ami megfelelő neki. Ez az indok ritkább, általában a gyerekek nagy részének is könnyebbség, hogy nem kell iskolába járni, inkább a munkával történő pénzkeresés vonzza őket.

A tanulás iránti motiválatlanságuk legfőbb oka a negatív szülői példa, a szülői iskolázatlanság. Nincsen semmilyen céljuk, a szakmát nem értékelik. A másik fó probléma, hogy hiába tanulnak a gyerekek, nincsen munkalehetőség, a gyerekek úgy nőnek fel, hogy azt látják, hogy a szülök nem dolgoznak. „, Sok roma szülö dolgozna, ha lenne munka, ezt látjuk az idénymunkák során, amikor a család apraja-nagyja mozgósítva van. Sok család minden lehetöséget megragadott, hogy tudjon menni. Ez is egy pozitiv példa lehet elöttük, hogy azért van 50 család, aki vitte valamire, mert dolgoznak és majd a lustább is elöbb-utóbb belátja, hogy ha a munka miatt egyik másik a lakását rendbe tudja tartani, nem éheznek stb... akkor én is megpróbálom. "(családgondozó)

A munka kapcsán a családsegítők közfoglalkoztatási programokkal - ismertebb nevükön közmunkaprogramokkal - kapcsolatos véleményére is kíváncsi voltam. Annyiban tartják jónak, hogy ezáltal bekapcsolódnak a szakképzetlenek is a munka világába, de tartós megoldást nem nyújt. Nem tartják jónak azt, hogy 
már 16 év után is részt lehet venni ilyen programokba, mert ez arra motiválja a szülőket, hogy kivegyék a gyereket az iskolából és beírassa közmunkára. " $A$ gyerekeknek 18 éves korukig az iskolában a helyük, tanulniuk kell, csak az iskolában látják a pozitív példákat, sajnos a szülöktöl nem." (családgondozó)

A 16 éves tankötelezettség negatív hatásának értékelik a családgondozók a korai gyermekvállalást. „,Amióta visszaállt a 16 éves tankötelezettség, annyi kisterhesünk van, ami évek óta nem volt, ez is egy megélhetési forrás, hiszen az anyukák már 16 éves koruktól megkapják a GYES-t. Azzal, hogy 16 év után nem kell tanulni, csak azt segitjük elö, hogy szülnek, családot alapitanak... ez megint nem a tanulásra ösztönzi öket, ráadásul ezek a fiatalkori kapcsolatok nem tartósak, a szülök külön mennek, a fiatal anyuka egyedül marad a gyerekkel, ettöl sérül a gyerek és így tovább, a gyerekek nincsenek felvilágositva." (családgondozó)

\section{A lemorzsolódás megakadályozásának lehetősé- gei a szociális szakemberek szerint}

A családgondozók úgy vélik, hogy elsősorban a szülők gondolkodásmódját kellene megváltoztatni. Erre jók lennének a klubok, csoportfoglalkozások, de ennek ellentmond, hogy a „roma szülők részéröl a látogatottság gyakorlatilag egyenlö a nullával." Mivel a foglalkozások önkéntes részvételen alapulnak, kényszeríteni nem lehet őket. A családgondozók tapasztalata szerint csak azokon a foglalkozásokon vesznek részt, ahol pénzt vagy valami kézzel fogható dolgot kapnak. A családgondozás keretében belül tájékoztatják, felvilágosítják őket, de családot csak jelzés alapján és a jogszabályi feltételeknek megfelelően lehet gondozásba venni.

Mivel a szülöket nagyon nehéz motiválni, kimozdítani, egyedül a gyerek az, akire fókuszálni kellene az iskolában, hiszen ott kapja meg a kedvet a továbbtanulás, szakmaszerzés iránt. „Az iskolán kívüli idöszakban akár gyereket, akár szülöt bármilyen rendezvényre nem lehet kimozditani, ez a réteg nehezen mozditható." (családgondozó)

A pedagógusnak kell motiválni arra, hogy tanuljon, legyen a gyerekek előtt célok. Fontosnak találják a kis létszámú csoportokban történő oktatást. „A roma gyerekek ingerszegény környezetbe születnek, onnan jobbik esetben bekerül óvodába, ahol kinyilik elötte a világ, fejlesztést kap, utána bekerül az iskolába, és azért nem mindegy, hogy egy ingerszegény környezetböl, egy 30 vagy 16 fös kis létszámú osztályba kerül, mert ott többet lehetne velük foglalkozni, kis létszámú csoportban, és erre már nincs erre lehetöség mostanában." 
Több gyakorlati oktatásra lenne szükség az általános iskolában, hogy megismerkedjenek a gyerekek a főzéssel, kerti munkákkal stb. A korai gyermekvállalás miatt több felvilágosító órára lenne szükség. Ezen kívül a tovább tanulás iránti motivációjukat kell erősíteni, több tájékoztató órával, előadásokkal. ,Mi is szerveztünk már több alkalommal prevenciós elöadásokat a gyerekeknek, de rengeteg a gondozott családunk, és ere egyre kevesebb az idő. "(családgondozó)

$\mathrm{Az}$ ifjúságvédelmi felelősre nagy szükség lenne a szociális szakemberek szerint. Ö volt az összeköttető személy, és nála futottak össze a jelzések az egész iskolából. Az osztályfönököt nehéz elérni, az ifjúságvédelmi felelős léte megkönnyítette a munkájukat, másrészről ő valóban tudott családot látogatni, fel tudta tárni a problémákat, szemben az osztályfönökökkel.

A családgondozók a 18 éves tankötelezettségi rendelkezéssel értettek egyet, mert sok gyereket az iskolában tartott, nagyobb esélyt adott a szakma megszerzésére. Fontosnak találták emellett a szülői felelősség hangsúlyozását. A kiskorú veszélyeztetettsége miatti szabálysértési eljárásoknak volt eredménye. A szankciók közül az iskoláztatási támogatás felfüggesztését pozitív intézkedésnek tartják, az a tapasztalatuk, hogy többségük arra törekedik, hogy visszaszerezze az elvesztett anyagi juttatást.

\section{A tankötelezettségi korhatár pozitív és negatív hatása a hatóság képviselői szerint}

A tankötelezettségi rendelkezés legfőbb hatása a hatósági munka e területein az eljárások számának változása: a gyámhatóság és szabálysértés területén csökkenés, a munkaügyi eljárás területén növekedés tapasztalható. Az iskoláztatási támogatás felfüggesztése tárgyú eljárások csökkenésének mögöttes okáról egyértelmüen nem lehet nyilatkozni, ugyanis okozhatja azt az igazolatlan hiányzások csökkenése, de okozhatja a tankötelezettségi korhatárt betöltők korai iskolaelhagyása is. Az ügyintéző az utóbbi okot érzi a háttérben a roma tanulók esetében, hozzátette, hogy az illetékességi területén az eljárások 90 százaléka őket érinti. A tankötelezettség megszegése szabálysértési eljárások csökkenésének oka, hogy nem kell eljárást kezdeményezni a tankötelezettséget követően a szülővel illetve tanulóval szemben.

A tankötelezettség csökkenésével egyidejüleg megnyílt a munkavállalás lehetősége a fiatalok számára. Akik úgy döntenek, hogy 16. évesen elhagyják az iskolát a szülö/törvényes képviselő hozzájárulással kezdeményezhetik álláskeresőként történő nyilvántartásba vételüket a munkaügyi hivatalokban. Az ügyintéző tapasztalata szerint a roma fiatalok körében ez gyakoribb jelenség. ,, $A$ 
szülői példát követve legtöbbször a közfoglalkoztatás motiválja őket. Életcéljukat megfogalmazni nem tudják, , lógnak” a levegöben. Az önkormányzati közfoglalkoztatásban biznak, a szakképzés megszerzése nem motiválja öket."(munkaügyi ügyintézö)

A közfoglalkoztatásban való részvételhez, ahogyan a nyilvántartásba vételi kérelem benyújtásához is, szükség van szülö/törvényes képviselő beleegyezésére 18. életkor betöltése elött.

A 16 éves tankötelezettségi korhatár jelentősen hozzájárul a korai iskolaelhagyáshoz a roma tanulók esetében, legfőképpen azért, mert egyébként sem motiváltak tanulás iránt. A tanulás iránti motiválatlanságuk oka elsősorban a szülöi minta, a szülői háttér. „A szülöi mintából adódik, itt a romák szakképzetlenek, nem motiválják a gyereket, nem is várják el (gyámügyi ügyintézö). "

Az ügyintézők a szegénységet nem emelték ki a korai iskolaelhagyást fö indokaként. „Aki akar tanulni, jelentős anyagi támogatás mellett teheti ezt meg.” (gyámügyi ügyintézö)

Az állam több csatornán keresztül támogatja a tanulókat, és nagy hangsúlyt kapnak a roma tanulók. A rendszeres gyermekvédelmi kedvezmény jogosultság biztosítja az ingyenes/kedvezményes étkezést, ingyenes/kedvezményes tankönyvet. Ez az ellátási forma a tankötelezettség csökkenésével is változatlan maradt, tehát a gyermek 18 éves koráig biztosított, függetlenül attól, hogy tanul vagy sem. Bár ez az iskolaelhagyók részére csak az évi kétszeri 5800 Ft/fö Erzsébetutalványt jelenti, mivel az 1997. évi XXXI. törvény alapján a többi kedvezmény az iskolalátogatáshoz kötött.

A tankötelezettségi rendelkezés változtatása szintén nem érintette a szülői felelősséget, ugyanúgy felnőttkorának betöltéséig a szülő felelős gyermekéért. Ettől eltérő szabályozás van a büntetőeljárások esetén.

A korai iskolaelhagyó fiatal kiskorú életkora miatt szociális ellátást sem igényelhet, szülői hozzájárulással sem, tehát egyedül megoldásként a munkavállalás, a közfoglalkoztatás elérhető a számukra. A rendszeres gyermekvédelmi kedvezmény, hátrányos és halmozottan hátrányos helyzetre való jogosultságon alapuló ösztöndíjprogramok jelentős segítséget nyújtanak tehát, amelyre további forrásokat célszerü biztosítania az államnak.

A tankötelezettségi rendelkezést a hatóság is összefüggésben látja a korai élettársi kapcsolat létesítésével, és a korai gyermekvállalással. A tankötelezettség ennek már nem szab korlátot, és lányok részére ez egyfajta megélhetési lehetöség is lett. 


\section{A lemorzsolódás megakadályozásának lehetősé- gei a hatóság szakemberei szerint}

A megkérdezettek szerint a gyerekeknek felnőttkoruk betöltéséig az iskolában a helyük. A romákat tekintve ezt különösen fontosnak tartják, a „kitöréshez” arra van szükség, hogy tanuljanak, iskolai végzettséget szerezzenek. A szakemberek úgy látják, hogy a gyerekek megfelelő fejlődéséhez szükséges feltételek az otthonukban nem állnak rendelkezésre, csak az iskolában. „Nem értek egyet azzal, hogy kikerül 16 évesen a szakemberek látóköréböl, mert ezeknek a gyerekeknek nem biztositott a megfelelö fejlödéshez szükséges környezetet, sokszor a napi kenyér sem. "(gyámügyi ügyintézö)

Az iskoláztatási támogatás felfüggesztését és a szabálysértési eljárásokat hatásos intézkedésnek tartják, szükséges tudatosítani és hangsúlyozni a szülői felelösséget. „Az iskoláztatási támogatás felfüggesztése egy pozitiv intézkedés, próbálnak arra törekedni a szülők, hogy az 50 óra ne jöjjön össze” gyámügyi ügyintéző.

A szabálysértési eljárások során a figyelmeztetés, pénzbírság kiszabására van lehetőség. Amennyiben a kiskorú veszélyeztetettsége fennáll, a bíróság elzárásról ítélkezhet. A szabálysértési eljárások során a felelősségre vonás nagyon körülményes, a hatóságnak bizonyítania kell, hogy mulasztás történt a szülö részéről, tehát felelős a gyermek igazolatlan hiányzásáért. A lakóhelytől eltérő településen tanulók esetében a bizonyítási eljárás különösen nehéz, hiszen a szülő nem vonható felelősségre akkor, ha nem tudja ellenőrizni és figyelemmel kísérni a gyermek iskolalátogatását. Ez a jelenség föként a középiskolákban tanuló gyerekeket és szüleiket érintik. Ebből a szempontból ez a szankció nem visszatartó hatású, másrészről a pénzbírság kiszabása a szegény körülmények között élő roma családoknál ritkán hoz megoldást, bár a közfoglalkoztatottság terjedése révén lehetőség nyílt a pénzbírság közvetlen letiltására.

A tankötelezettség negatív hatásainak kiküszöbölésében a hatóságok a pedagógusok, és a segítő szakemberek munkáját érzik fontosnak. Kiemelték a gyermek veszélyeztetettségét észlelö-, és jelzőrendszer megfelelő müködésének fontosságát. Ez hozzájárul az időbeli és hatékony segítségnyújtáshoz.

A pedagógusok és a segítő szakma feladatának tartják, hogy a roma tanulók szabadidejének hasznos eltöltésére különböző programokat szervezzenek, különösen a nyári időszakban. Szükségesnek találják a felvilágosító, szakmabemutató programokat.

A szociális ügyintéző részéről felmerült, hogy a különböző felvilágosító, életvezetéssel, továbbtanulással stb. kapcsolatos programokon történő részvétel beépülhetne a szociális ellátásokra jogosultsági feltételeibe, egyfajta együttmüködési kötelezettségként. Ezt azért tartja fontosnak, mert nehéz a szülöket, külö- 
nösen a roma szülöket az önkéntes részvételen alapuló segítő foglalkozásokba bevonni. Ezek az előadások, programok a segítő szakma közremüködésével megcélozná a különböző célcsoportokat: nőket, a mélyszegénységben élőket, romákat, munkanélkülieket stb. Fontosnak tartják ezeknek a lehetőségeknek a minél szélesebb körben történő propagálását: ,, Sokan nem tudják, milyen lehetöségeket rejt egy-egy program” (gyámügyi ügyintézö)

\section{A tankötelezettségi korhatár pozitív és negatív hatása az szülők szerint}

A 16 éves tankötelezettségi korhatárral kapcsolatos vélemények megoszlottak a megkérdezett szülők körében, de egyöntetüen a rendelkezés fő hatásának azt tartják, hogy a tanulók elhagyják az iskolát a végzettség megszerzése előtt. Ez két szülő (édesanyák) szerint negatív, egy szülö (édesapa) szerint csak részben negatív hatás. Utóbbi véleménye szerint a gyerekek minél előbb munkába szeretnének állni, hogy ezzel is tudják támogatni a családjukat, és ez nem rossz dolog. ,Van most már közfoglalkoztatás nekik, amely szerintem megoldás lehet a tankötelezettség befejezésénél, tanfolyamokon is el tudnak helyezkedni, ha a munkaügyi központban regisztrálnak, és ezért már ök pénzt kapnak és motiválja öket. Inkább az motiválja a szülöket is, ha a gyerek hazavisz 50e Ft-ot, mint hogy csak viszi el az oktatásra a pénzt."

Ezzel a véleménnyel ellentétben a megkérdezett édesanyák így nyilatkoztak a 16 éves tankötelezettségi korhatárral kapcsolatban: „Ez rossz, én nem engedélyezném, az a hatása, hogy otthagyja az iskolát. Úgy mondják nekik a szülök, hogy jó, betöltöd a 16 évedet, nem kapod a családit, mész a munkanélkülibe regisztráltatod magad, mint pályakezdö felvesznek dolgozni, erre a közhasznúra. Én már ezt nagyon sok szülötöl hallottam, nem egy-kettötöl. Nem is alkalmazzák amúgy meg, még nem olyan annak a felfogása, csak gyerek, a 16 éves gyereknek az a dolga, hogy tanuljon."

„, Azért nem járnak, mert 16 év a tankötelezettség, és erre utaznak, mert ha 18 lenne, akkor minden szülö már csak azért is üzné a gyereket, hogy járjon a családi pótlék, és az alatt is szakma lenne. Nem jó ez, éppen hogy csak a 8 osztályt elvégezze, nem munkára való egy 16 éves, esetleg nyári munkára."

A vélemények alapján elmondható, hogy a munkanélküliként történő regisztráció, a támogatott tanfolyamok, és a közfoglalkoztatás lehetősége csábítóan hat a tanulókra, a szülőkre. Ez a szegény életkörülményeknek tudható be, keresik azokat a lehetőségeket a családok, amellyel több pénzhez juthatnak. A legfóbb motiváló erőnek tehát a pénzt tartják a megkérdezettek. A tanulót ez a motiváló 
erő viszont kétfelé húzza, egyfelől a tanulás felé, ahol a különböző ösztöndíjpályázatok vannak, és szakmát szerezhet, másfelöl a munkaügyi központok által biztosított képzések, vagy közmunkaprogramok felé, ahol bekapcsolódhat a munka világába. A választása attól függ, hogy milyen a szülooi minta. A szülői példa fontosságát minden szülő kiemelte.

„Ezek a gyerekek hátrányos helyzetüek, nem rendelkeznek családi háttérrel, támogatottsággal, ami azt fejezné ki, hogy minél elöbb elöre haladjanak, minél nagyobb iskolát szerezzenek, mert nekik elfogadott a közmunka, mivel jelentös mértékben közmunkás háttérböl kerülnek ki, egy diplomás szülö nem szeretné, ha a gyereke diploma nélkül marad, egy 8 általános nem fog arra törekedni, hogy magasabb iskolai végzettség legyen, mert nem tud kifinanszírozni egy egyetemet." (édesapa)

„A roma gyerekek között is van olyan, aki igenis akarna tanulni, de a szülök elszúrják. A gyereknek is akarni kell, meg a szülönek is, hogy akarja rávezetni, hogy igenis tanulni kell, mert a mai világban, hogy elmenjen szociálisra, abból soha nem fog megélni. "(édesanya)

A közfoglalkoztatási programok többször is szóba kerültek az interjúk során pro és kontra: két édesanya ellene, édesapa mellette. ,...csak arra jó, hogy éhen ne haljanak, én azt mondom, hogy szakmát szerezzen, utána munkát, az egy állandó megélhetés, inkább mint a közmunka, mert ez nem folyamatos, azután a pár hónap után újra kapja a 22800-at, és abból hol tart fent egy családot például...."(édesanya)

A tankötelezettségi korhatár negatív hatásaként említette két szülő is a korai szülés problémáját. „,...erre kellene megoldás, én mindig azt mondom nekik, hogy elöször próbálják alapozni az életüket, majd ráérnek még családot alapitani. A gyermekjóléti szolgálatnak jobban oda kellene erre figyelni, de nem lehet egy gyámügyes a hibás, a szülőnek kéne odafigyelni rájuk..."

Az édesapa pozitívumként fogja fel, hogy ez a rendelkezés megkönnyíti a tanárok helyzetét, ,, egyfajta segitség” nekik, mert így nem kötelesek megtürni a 18 éves gyereket a nála akár 3-4 évvel fiatalabb tanulókból álló csoportban, amely egyébként nem tesz jó a többi gyereknek.

\section{A lemorzsolódás megakadályozásának lehetőségei a szülők szerint}

A megkérdezettek mindegyike kiemelte a különböző ösztöndíjpályázatok fontosságát. Saját börükön érzik ennek a pozitív hatásait, minden megkérdezett családjában van olyan tanuló, aki részt vesz valamely pályázatban (Arany János 
Kollégiumi- Szakiskolai Program, Útravaló program általános iskolában és középiskolában). Főként ezeket a programokat emelték ki a megoldásként. (Másik megoldásként hangzott el a korábban kifejtett közmunkaprogramok, munkaügyi központ általi képzések.) A gyerekek az ösztöndíjak miatt motiváltak a tanulásban, jól tanulnak, végzettséget akarnak szerezni, sőt az érettségi megszerzését is kitüzték célul. ,ha nem lenne ez a program (Arany János Kollégiumi- Szakiskolai Program), nagyon nehéz lenne, nem tudnám finanszírozni, lehet, hogy nem tudná tovább folytatni a tanulást." (édesanya)

Szükségesnek tartják a szülők ezeknek a programoknak a népszerüsítését, különösen a kollégiumi programot, amely mindenféle támogatást nyújt a tanulónak (ruhapénz, élelmiszerpénz) ,Szeret ott lenni, jó körülmények között van, elöször féltünk töle, de most már látjuk, hogy ez nagyon jó neki, haza sem akar jönni, ha itthon van, alig várja, hogy menjen visszafelé. A kollégiumban nagy a fegyelem, tisztaság van, szilenciumon tanulnak, ellenörzik öket. Ha bejárós lenne, akkor rontott volna már sokat, mert mire hazaérne, fáradt lenne, és nem tanulna. Meg van olyan tananyag, amihez mi nem értünk, és nem tudok neki segiteni, ott meg vannak tanárok. Én kollégiumba helyezném a legtöbb roma gyereket, itthon elfognak kajlódni. "(édesanya) Több pozitív példával lehetne a szülők és a tanulók gondolkodásmódján változtatni. Meg kell ismertetni a tanulókkal a kollégium által biztosítottakat, több olyan programot kell szervezni, amitől kedvet kapnak. Különböző oktató jellegü programok, foglalkozásokkal, rendszeres kulturális napokkal, vagy olyan érdeklődésüket kellene felkelteni, tudás iránt érezzenek vágyat. A szülőket is célszerü ezekbe bevonni: ,, szülőként is érdekessé válhat egy ilyen" (édesanya).

A tankötelezettségi rendelkezéssel részben egyetértő apuka kiemelte, hogy több olyan közfoglalkoztatási programot célszerü indítani, amely munkát biztosít azoknak a gyerekeknek, akik nem akarnak tanulni.

$\mathrm{Az}$ iskoláztatási támogatás felfüggesztésével minden szülö egyetértett, ezeknek a további szigorúbb szabályzását is támogatnák. Ezzel hangsúlyozzák a szülői felelősséget, kötelezettséget és úgy látják, hogy visszatartó hatása van:, $A$ rossz gyereket is bekényszeriti az iskolába, és jó viselkedésre kényszeriti." (édesapa) „,...amúgy ennyit sem lennének bent az iskolában” (édesanya)

Egy szülő megemlítette, hogy fontos lenne az általános iskolai oktatás fejlesztése, hogy többet foglalkozzanak a roma tanulókkal, mert sokszor kevés a középiskolában a megszerzett általános iskolai tudás, ezáltal sokat ront a gyermek és kudarcélmény miatt elveszíti a tanulás iránti motivációját. 


\section{Megbeszélés}

A tankötelezettségi korhatár csökkentése az iskoláknak bizonyos könnyebbséget hozott, hiszen nem kell azokat a diákokat 18. életévük betöltéséig az iskolában tartani, akiknek a tanulás kényszer volt, emiatt motiválatlanságukkal, esetleges deviáns magatartásukkal megnehezítették a pedagógusok munkáját. Korábban ezek a gyerekek 18 éves koruk után is jellemzően végzettség nélkül hagyták el az iskolát. A tankötelezettségi rendelkezést tehát az oktatás körülményei és a statisztika szempontjából pozitív döntésnek tartják az iskolaigazgatók. Másrészről egyetértettek abban, hogy a hátrányos, halmozottan hátrányos gyerekek, különösen a roma gyerekek fejlődése érdekében szükséges, hogy felnőtt koruk betöltéséig az iskola fejlesztő környezetében legyenek, müvelődjenek.

Statisztikai szempontból pozitívan hat a rendelkezés a hatósági eljárásokra is, hiszen a szabálysértési-, és az iskoláztatási támogatás felfüggesztése tárgyú eljárások száma is mérséklődött. A rendelkezés pozitív hatása továbbá a magántanulói státuszok csökkenése. Korábban ezzel a lehetőséggel a szülők rendszeresen éltek, ha a gyermeküket nem bírták rávenni az iskolába járásra. A magántanulók általában sikertelenül fejezték be a középiskolát. A pozitív hatással szemben áll, hogy a korhatár leszállítását követően változott a lényeg: ezek a fiatalok végzettség nélkül lépnek ki a munkaerö-piacra.

A tankötelezettségi korhatár csökkenése megkönnyíti a roma tanulók korai iskolaelhagyását, sőt, a nyomorban élő családok anyagi szükségletei miatt fel is erősíti az iskolai végzettség nélküli kilépést. A korhatár leszállítása az iskolaelhagyás legális eszközeként funkcionál. A tankötelezettségi korhatár csökkenésével a 16. életévét betöltött fiatal számára lehetőség nyílik arra, hogy eldöntse: folytatni kívánja-e tanulmányait, vagy inkább munkába áll. Törvényes képviselöjének hozzájárulása mellett dönthet: tanul vagy dolgozik. A munka világa a roma fiatalokra - tanulás iránti motiválatlanságukból fakadóan - csábítóan hat.

Vizsgálatom során előtérbe került, hogy tankötelezettségi rendelkezés ösztönzően hat a roma lányok korai gyermekvállalására is. Mivel a korai gyermekvállalás nem áll messze a roma családok hagyományaitól, legális és elfogadott menekülö utat biztosít azoknak a lányoknak, akik nem akarnak tanulni. Egyúttal jövedelemszerzési, és ezzel megélhetési lehetőséget is látnak a családalapításban, hiszen a gyermekgondozási segélyt már 16 éves korukban is megigényelhetik. A segítő szakma szerint ezek a fiatalok még nem érettek az anyaságra, ezek a kapcsolatok felszínesek, nem tartósak, a szülők hamar különválnak, az anyák egyedül maradnak, amely a gyermek veszélyeztetettségének kialakulását, sérülését eredményezi. 
Összességében elmondható, hogy a tankötelezettségi rendelkezés pozitív hatásai csupán a szakember eszközhiányosságának szemszögéből látva pozitívak (nem kell bajlódni a motiválatlan gyerekkel, nem jön jelzés), és a kudarcos ,ügyektől” való részbeni megmenekülés ez az előny. Ugyanezen dolgok a gyerek szemszögéből nézve (nincs, aki bajlódjon vele, nincs aki jelzést kapjon róla) már sokkal negatívabb fénybe kerülnek, ráadásul a menekülési útvonal miatt biztosan nem számíthatunk semmilyen változásra, amely a szakemberek eszközhiányos állapotán változtatna. Azaz az új szabályozás nem azt hozta, hogy „csináljuk jobban” (a probléma megoldását) hanem azt, hogy „,ne csináljuk egyáltalán” (tollvonással szüntessük meg a problémát).

\section{Felhasznált irodalom}

1. Ambrus P. (1988): A Dzsumbuj: egy telep élete. Magvető Kiadó, Budapest.

2. Babusik F. (2003): Késői kezdés, lemorzsolódás - Cigány fiatalok az általános iskolában. Delphoi Consulting, Budapest.

3. Babusik F. (2004): A szegénység csapdájában. Delphoi Consulting, Budapest.

4. Fábián G., Szoboszlai K. és Hüse L. (2011): A „kamatos pénz” - az uzsorakamat intézménye telepszerü körülmények között élők körében. In: Bódi F., Fábián G. [szerk.]: Helyi szociális ellátórendszer Magyarországon. Debreceni Egyetemi Kiadó, Debrecen. 179-199.

5. Fábián, G., Szoboszlai, K. és Hüse, L. (2012): „Money with interest” - The institution of usury among those living in slum-like conditions. In: Bódi, F., Fábián, B., Lawson, T. R. [eds.]: Local Organization of Social Services in Hungary. Studies in Comparative Social Pedagogies and International Social Work and Social Policy, Vol. XXII. Europäischer Hochshulverlag, Bremen. 242-267.

6. Fehér K. és Virág T. (2011): Élet egy kisváros peremén. Tér és Társadalom, 28. évf., 3. szám. 50-65.

7. Fehérvári A. (2008): Lemorzsolódás a szakiskolákban - egy empirikuskutatás tapasztalatai. In: Fehérvári (szerk.): Szakképzés és lemorzsolódás. Oktatáskutató és Fejlesztő Intézet, Budapest. 165-281.

8. Fejes J. (2005): Roma tanulók motivációját befolyásoló tényezők. Iskolakultúra, 11. 3-13.

9. Forray R. K. (1997): Az iskola és a cigány család ellentétei. Kritika, 7. 1619.

10. Forray R. K. és Hegedüs T. A. (1998): Cigány gyermekek szocializációja. Aula Kiadó, Budapest. 
11. Forray R. K. és Pálmainé O.A. (2010): Hátrányos helyzetü vagy kulturális kisebbség - cigány programok. Educatio1 8, 2. 75-87.

12. Girán J. és Kardos L. (1997): A cigány gyerekek iskolai sikertelenségeinek háttere. Iskolakultúra 7. 10. melléklet.

13. Havas G. (1999): A kistelepülések és a romák. In: Glatz F. (szerk.): A cigányok Magyarországon. Magyar Tudományos Akadémia, Budapest. 163-203.

14. Hermann Z. és Varga J. (2012): A népesség iskolázottságának előrejelzése 2020-ig. Közgazdasági Szemle, LIX. 854-891.

15. Hüse L. (2008): A kirekesztés diskurzusa. Kapocs VII/5: 2-23.

16. Hüse L. (2011): Kettős mérce az iskola szerepének megítélésében - egy kirekesztés-kutatás margójára. Iskolakultúra 2011/1: 88-98.

17. Hüse L. (2013): Üvegplafon és detektívtükör. Etnikai határok a társadalomban. In: Deme D., Molnár E. [szerk.]: Evangélikus Roma Szakkollégium 2012/2013-as évkönyve. ERSZK, Nyíregyháza. 63-88.

18. Hüse L. (2015): Roma tanulók iskolai attitüdjeit befolyásoló tényezők. Szakkollégiumi Tudástár 1. ERSZK, Nyíregyháza.

19. Hüse L., Balogh E., Barnucz N., Fónai M. és Zolnai E. (2014): The discourse of social exclusion and its benefits for the majority. In: Liberska, H., Farnicka, M. [eds.]: A Child of many Worlds: Focus on the Ethnic Minority Problem. PETER LANG GmbH Internationaler Verlag der Wissenschaften, Frankfurt am Main. 47-66.

20. Hüse L., Fábián G. és Szoboszlai, K. (2013): Uzsora a végeken. Café Bábel 70: 81-87.

21. Hüse L., Szoboszlai K. és Fábián G. (2006): A semmi ágán... - Hátrányos helyzetü csoportok sérelmére elkövetett cselekmények kutatása. Periféria Egyesület, Nyíregyháza.

22. Hüse L, Szoboszlai K. és Gurály E. (2015): Egy falukutatás fókuszában: a gyerekszegénység. Szakkollégiumi Tudástár 3. ERSZK, Nyíregyháza.

23. Istenes M. és Péceli M. (2010): Tankötelezettségi korhatárok nemzetközi összehasonlításban. Iskolakultúra, 2010/4: 3-22.

24. Janky B. (2004): A cigány családok jövedelmi helyzete. In: Kolosi T., Tóth I.GY., Vukovich GY. (szerk.): Társadalmi riport. TÁRKI, Budapest. 400413.

25. Józsa K. (2002): Tanulási motiváció és humán müveltség. In: Csapó B. (szerk.): Az iskolai múveltség. Osiris Kiadó, Budapest. 239-268.

26. Józsa K. (2006): A képességek és motívumok kölcsönös fejlesztésének lehetősége. In: Kelemen E., Falus I. (szerk.): Tanulmányok a neveléstudomány köréböl. Müszaki Könyvkiadó Kft., Budapest.

27. Kemény I. (1976): A magyarországi cigányok helyzete. In: Kemény I. (szerk.): Beszámoló a magyarországi cigányok helyzetével foglalkozó, 1971ben végzett kutatásról. MTA Szociológiai Kutató Intézet, Budapest. 7-63. 
28. Kende Á. (2001): A kudarcok okai. In: Andor M. (szerk.): Romák és oktatás. Iskolakultúra, Pécs. 65-74.

29. Kertesi G. (1995): Cigány gyerekek az iskolában, cigány felnőttek a munkaerőpiacon. Közgazdasági Szemle, 1. 30-65.

30. Kertesi G. és Kézdi G. (2010): Iskolázatlan szülők gyermekei és roma fiatalok a középiskolákban - Beszámoló az Educatio Életpálya-felvételének2006 és 2009 közötti hullámaiból. Magyar Tudományos Akadémia Közgazdaságtudományi Intézet. Budapest.

31. Kertesi G. és Kézdi G. (2012): A roma és nem roma tanulók teszteredményei közti különbségekről és e különbségek okairól. Magyar Tudományos Akadémia Közgazdaságtudományi Intézete, Budapest.

32. Kiss J. és Gordos Á. (2003): Családi és kortárskapcsolatok jellemzői általános iskolás roma és nem romagyermekek körében IV. Egészségnevelés, 44.100-108.

33. Ladányi J. (1989): A lakásrendszer változásai és a cigány népesség térbeni elhelyezkedésének alakulása Budapesten. Valóság, 6., 73-89.

34. Ladányi J. és Szelényi I. (2004): A kirekesztettség változó formái. Napvilág Kiadó, Budapest.

35. Liskó I. (2002): A cigány tanulók iskolai eredményei. In: Reisz T., Andor M. (szerk.): A cigányság társadalomismerete. Iskolakultúra, Pécs. 174-194.

36. Mártonfi GY. (2011): A 18 éves korra emelt tankötelezettség teljesülése és (mellék)hatásai. Oktatáskutató és Fejlesztő Intézet, Budapest.

37. Mártonfi GY. (2013a): Korai iskolaelhagyás a magyarországi szakképzésben. Oktatásfejlesztési Observatory Központ Budapesti Corvinus Egyetem, Budapest.

38. Mártonfi GY. (2013b): Hiányszakmát tanuló végzős szakiskolások kutatási beszámolók - A felmérés néhány tanulsága. Új Pedagógiai Szemle, 1-2. 59-67.

39. Nagy J. (2000): XXI. század és nevelés. Osiris Kiadó, Budapest.

40. Nagy M. (2002): Cigány tanulók az iskolában. A tanárok beszélnek. Magyar Pedagógia 102/3: 301-331.

41. Pásztor I. és Pénzes J. (2012): Foglalkoztatási krízis és jövedelmi periferizálódás Északkelet-Magyarországon a roma népesség arányainak tükrében. Területi statisztika, 4. 353-371.

42. Polónyi I. (2002): A cigány népesség demográfiai, iskolázottsági és foglalkoztatási helyzete - s az abból adódó oktatáspolitikai következtetések. In: Reisz T., Andor M. (szerk.): A cigányság társadalomismerete. Iskolakultúra. Molnár Nyomda és Kiadó KFT, Pécs. 133-150.

43. Solt O. (1998): A hetvenes évek budapesti szegényei. In: Eörsi J., Havas G., Kemény I. (szerk.): Méltóságot mindenkinek. Összegyüjtött írások. Beszélő, Budapest, 242-288. 
44. Szuhay P. (1999): Foglalkozási és megélhetési stratégiák a magyarországi cigányok körében. In: Glatz F. (szerk.): A cigányok Magyarországon. Magyar Tudományos Akadémia, Budapest. 139-163.

\section{Pap Mónika}

Debreceni Egyetem, Egészségügyi Kar 